\title{
National Dental Conference: Best Practice 2001
}

\section{Compassion, enthusiasm, or an opportunity for a laugh - three attitudes to the older patient typify the diversity on offer at the Harrogate BDA conference. Elinor Parker reports on the successful three-day event.}

$\mathrm{H}$ ow do dentists cope with the ethical imperative of making dentistry available to those on modest incomes? At the BDA Conference in Harrogate one could choose to hear how adhesive materials are used in the private marketplace of American dentistry to conserve tooth tissue, eliminate most laboratory work and reduce prices. Or listen to the latest on the complex NHS system of government initiatives, regulations, incentives and payments.

\section{'Spoiled for choice'}

The diversity of the profession was evident from all the other choices on offer: the opportunities and challenges posed by the growing cohorts of the dentate elderly; a question and answer session on 'going private'; restorative panel presentations; the role of bacteria. There were poster displays ranging from basic science to what would be one's most likely reason for getting 'struck off'.

A session on transcultural issues posed the question of why Vietnamese children had the worst teeth of all the ethnic groups. An account of the miracle properties of ozone in the treatment of caries had people queuing up to spend $\mathfrak{1} 10,000$ on a new machine. Or one could learn how to do defensive dentistry, and who could give consent. 'I felt I was spoiled for choice', said delegate Dr Kate Allan, 'the scientific lectures

\section{Best Practice 2001 facts \& figures}

- Almost 2,000 delegates attended, the largest number ever at a BDA conference

- Exhibition stand space sold out in record time and there was a waiting list after that! were very good'. Temporary, reversible, selfcloning would be a useful technique for multiple-choice conferences.

\section{Late convert}

The session on the ageing patient was cheered by the enthusiasm of Dr. Harold Prieskel, who had flown himself from London. A late convert to implants, he was an inspiring speaker in favour of that current Cinderella, the partial denture, with or without implant support.

Professor Graham Mulley was well received on stereotyping and prejudice about older people, including the effects of demeaning representations on television and advertisements. He warned against Conference 2001. over-familiarity and patronising attitudes in clinical settings. His audience was impressed by his compassion and respect. Delegate Dr. Penny Joseph expressed a wish to be cared for by someone of that calibre herself when the (distant) time came. Another speaker used a photograph of a very old patient as a vehicle for his admittedly clever sense of humour. But I'm glad it wasn't my relative everyone laughed at.

By contrast, in the oversubscribed restorative session, which had to be repeated, Dan Fischer, of Ultradent Products and Loma Linda University, extolled his marvellous elderly patients in an enthusiastic presentation. His pictures of them were opportunities for him to tell us how wonderful they were, and how important that age group is as purchasers of our services.

Workshops were oversubscribed on two days and food almost ran out at lunchtimes, indications of dentists hungry for knowledge, and chicken sandwiches. Exhibitors reported an upbeat mood and stalls run by groups and associations were busy. The sci-

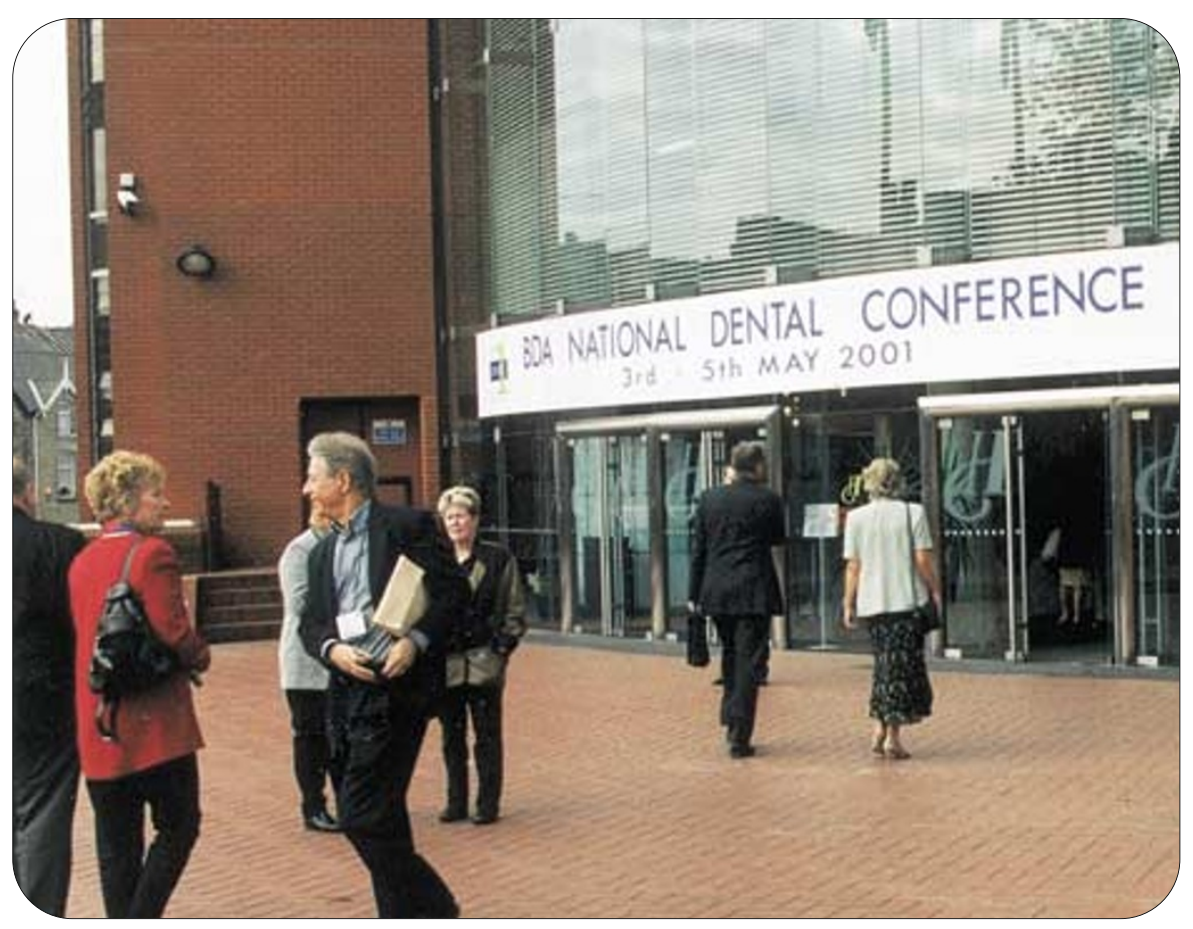

The Harrogate International Centre - location for this year's BDA Best Practice 
entific, political and managerial sessions were linked, somewhat tenuously, to the 'Best Practice' theme, to coincide with the launch of the BDA 'good practice' award scheme.

\section{Sustaining the unsustainable}

For an assessment of the state of UK dentistry delegates were able to hear Perri 6 admit that the first Demos think tank report had labelled the current system 'unsustainable' and that to his astonishment nothing fundamental had changed in the intervening years. Those who previously thought him hard on the Conservative government of the time were interested to hear his opinion that New Labour's 'NHS modernised' was really just 'NHS patched up'.

'The government has ended the emphasis on registration', he stated, but warned that 'access will not help the public health objectives. The cost of stopping the time haemorrhage of dentists from the NHS is much greater than the government envisages. Politician's priorities are elsewhere in the NHS.'

\section{Dislocation}

The audience then heard Lord Hunt acknowledge that his department was still having to cope with 'the effects of the 1992 fee cut, when a bond was cut that has never been mended.' He called for the 're-engagement of the profession with the NHS' and asked his audience to 'learn from history, not repeat it'. He acknowledged that transferring payments from health authorities to the DPB had resulted in a dislocation of dental services from local NHS structures. Lord Hunt announced that agreement had been reached on a 'single pay spine' for all the salaried services.

The Department would be inviting GDPs to bid for sessions to treat unregistered patients referred from access centres and NHS Direct. They will receive a sessional payment and be able to claim item of service fees. A fund of $\mathfrak{E} 35$ million will be available for new investment in practices that are willing to make a commitment to continuing in the NHS. He acknowledged the help of the BDA in setting up the various recent initiatives. His speechwriter was at odds with the department's officers, however, in having him state, during the delay in implementation, that clinical governance is now a requirement'. He announced the 'Focus Awards' to recognise good NHS practices, a joint initiative between the Department and the BDA.

\section{Seamless provision}

Other speakers in the main session included Tom Dowell, Chair of Avon Health Authority, who was forthright on current problems, including the failure to fluoridate, but was hopeful of some progress now. He warned that access centres are likely to cost $50 \%$ as much again to provide dental services compared with the GDS'.

Ros Hamburger, Consultant in Dental Public Health, Birmingham, gave a very positive account of coping with the problems of non-affluent areas. She was realistic about the disincentives for the GDS in such areas. Her schemes seem to produce a seam-

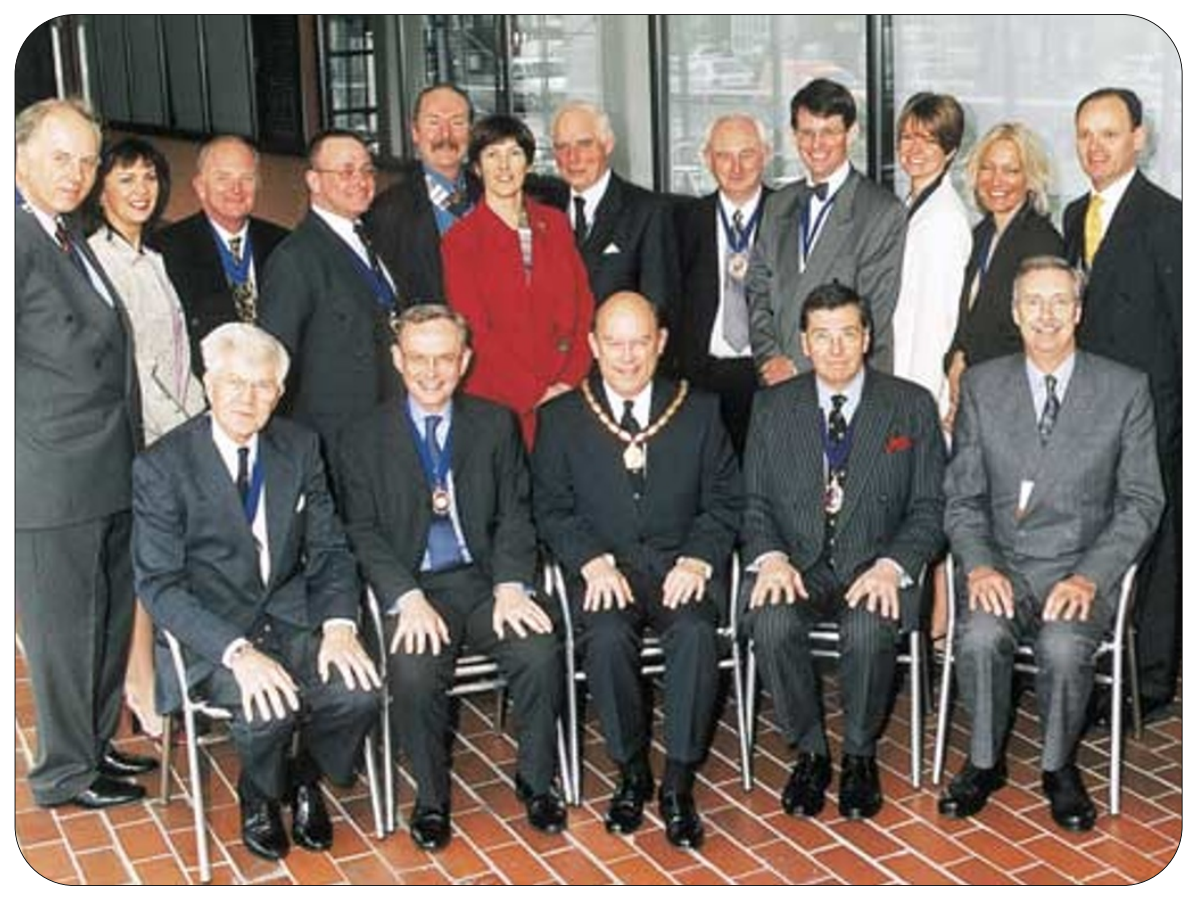

New BDA President Peter Swiss with some Branch and Group Presidents.

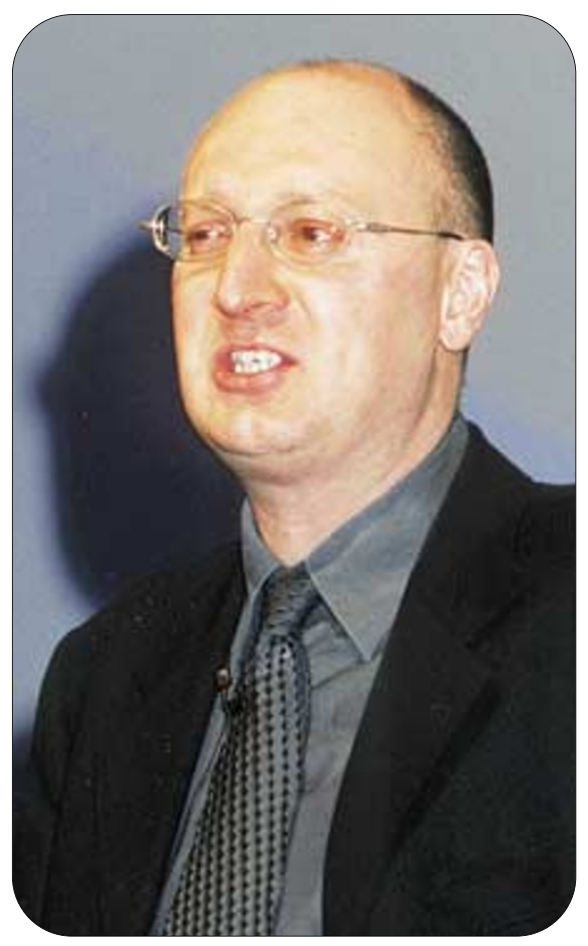

Speaker Perri 6 told delegates that New Labour's 'NHS' modernised was really just 'NHS patched up'.

less provision of access, education, liason with other social regeneration initiatives, emergency services and upgraded premises. 'But all this would founder without our linking in to general practices for ongoing care' she declared. 'We are providing rewarding and attractive jobs and have no difficulty in recruiting staff.'

\section{Fewer crowns}

The restorative session, which was oversubscribed, started with a very enthusiastic father of fourteen children, Dan Fischer. 'I only do one-eighth of the crowns that I used to do', he declared. 'Adhesive dentistry means the material can meet the needs of the tooth. We no longer need to remove tooth structure to meet the needs of the material.'

He advocated using caries indicators and slow rotary instruments to remove soft stuff to which you can't bond, but not to remove hard stuff'. By sealing, bonding and desensitising, minimally invasive techniques can make costs low enough for everyone to be able to afford good dentistry, he declared. His presentation of portraits of nonagenarian patients was shown to remind his audience that 'the 85 plus age group is increasing exponentially' and was done with loving respect. 'We are in the best people profession, this is a fabulous people profession', he asserted. 'What we have to do is listen to and serve human needs. We must 


\section{NEWS \& NOTES best practice}

offer not procedures, but a philosophy of practice. Be the eternal student, it's fun!' How come only Americans can be that inspiring?

\section{Miracle cure?}

If you haven't heard of ozone as the miracle dental cure, prepare to be amazed. 'Ozone disinfection kills $99 \%$ of the bacteria in a carious lesion within 10 seconds. After three to five months the lesion becomes hard, sometimes harder than the surrounding tooth tissue'.

Professor Edward Lynch reported the results of trials of ozone treatment of root caries and pit and fissure lesions being carried out in Belfast. This is part of a multicentre project using a machine which delivers ozone to the lesion and scavenges it back, resulting in lower levels in the mouth than in the street outside. Ozone is a strong oxidant and may be of use in sterilising dental water lines and root canals as well as cavities. Antibodies to Legionella are higher amongst members of the profession than in the general public, so the ones at risk from our tubing may be ourselves! The company, (CurOzone Co., USA) is refraining from any media promotion until professional trials are completed and available to the profession. They expect to launch the units at the end of this year.

\section{Head-banging}

'If you are tempted to prepare a double abutment for a bridge, leave the surgery. Walk to the nearest wall and bang your head

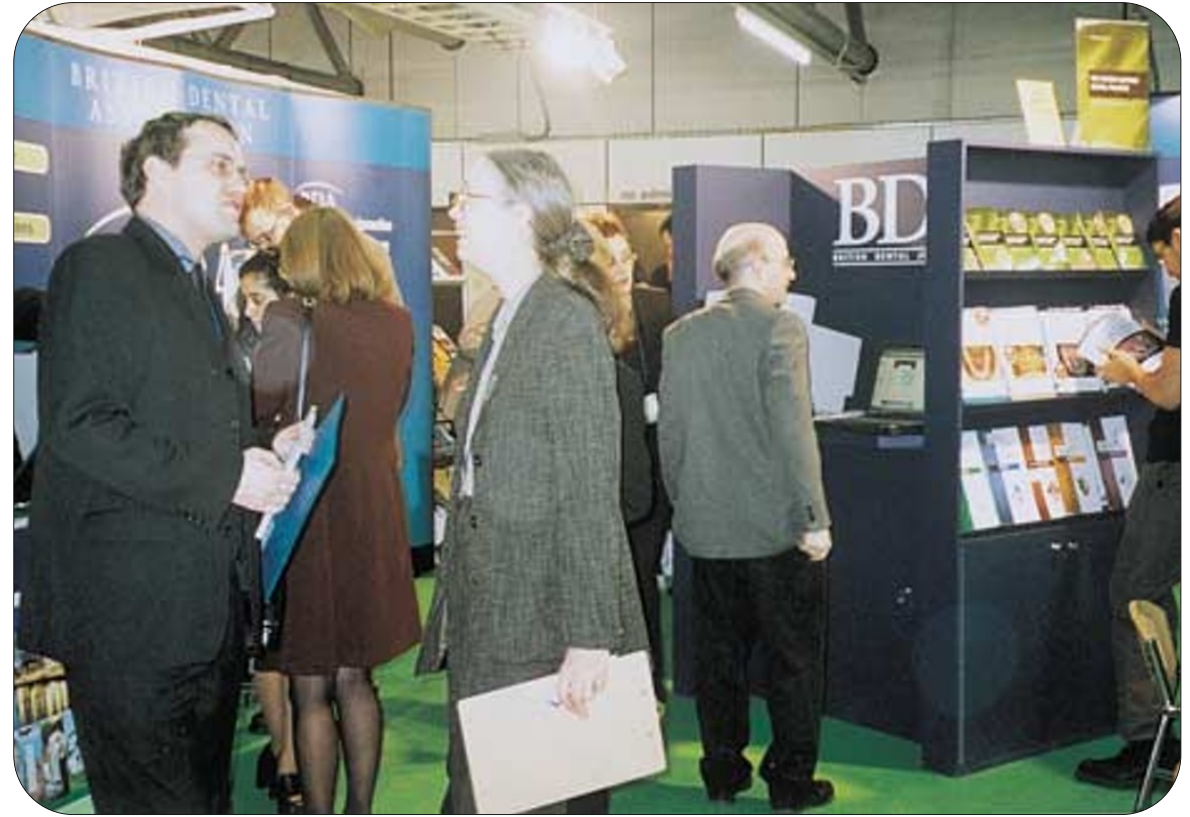

The BDA stand where delegates visited for information and advice. against it until the intention recedes. Return to your patient'. This apparently is Dr Richard Ibbetson's advice as relayed to the audience for the crown and bridge question and answer session.

Participation and short presentations from the panel kept up the pace for over three hours. People drifted in, but not out. The questions defined the topics, which ranged through posts (don't if you can avoid them, and never ceramic), cements (Panavia is very effective, zinc phosphate is retrievable), molar cores (amalgam), cantilevers (in), double abutments (out),

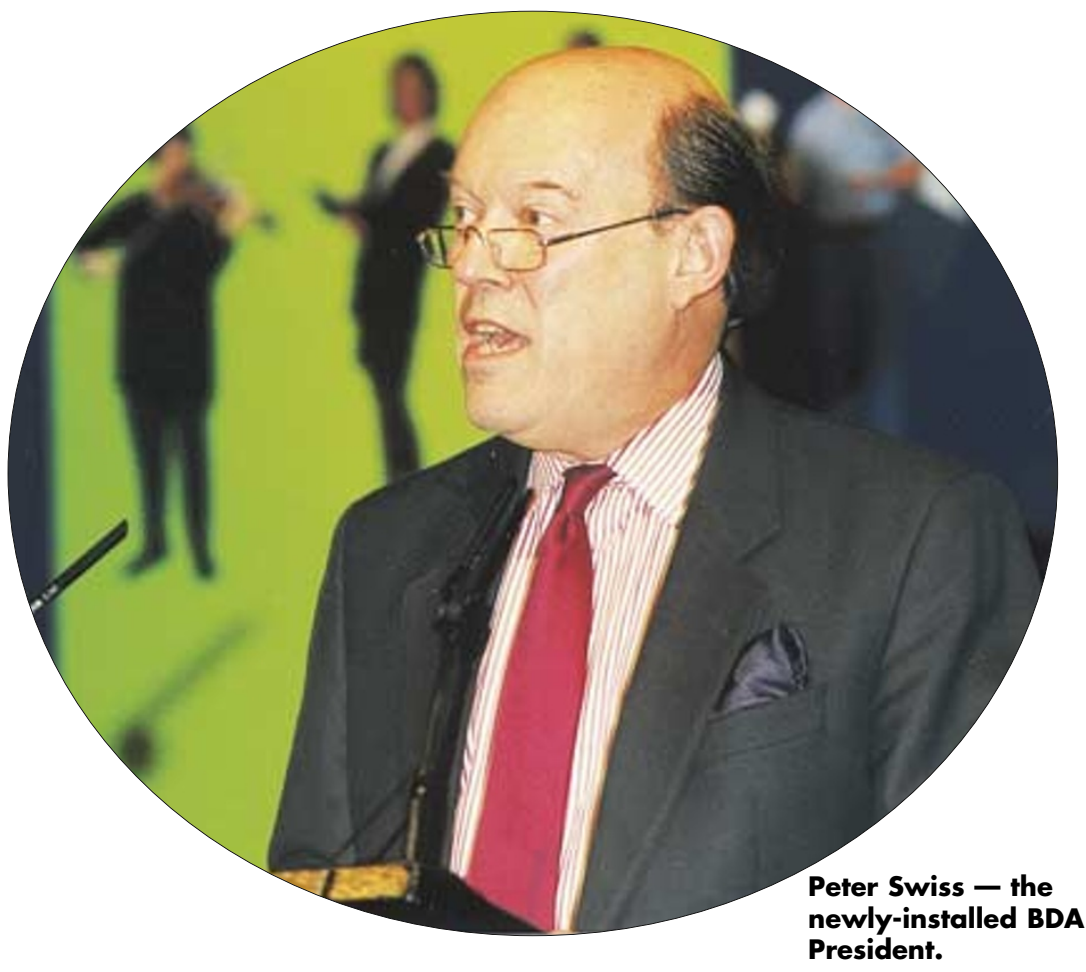

veneers (the average preparation has $20 \%$ exposed dentine) and many more. The problems of using root-filled teeth and those which have been subject to periodontal disease were aired. The consensus seems to be that if disease has been successfully treated then restoration can go ahead. Extra care with consent and record keeping was advised. However, the global success rate of $60 \%$ for endodontic treatment drops to less than $45 \%$ if a post and core is then placed. The role of implants instead of heroic measures of poor prognosis had support, although the financial barrier was at least mentioned. The opposing view was that 'a tooth is a $100 \%$ biocompatible implant'.

\section{Language problems}

Many societies and organisations laid on parallel meetings in the conference centre and in other hotels throughout Harrogate.

Delegate Dr Carolyn Devlin said that the conference now ranked for her with the standard of American conventions in breadth and organisation. The Women in Dentistry Lunch and Learn, on 'Transcultural issues within Dentistry', was given by Professor Sonia Williams. Prepared for a worthy PC yawn I actually found it fascinating.

An oral health video aimed at the Indian subcontinent community, a song in the vernacular tongue about the dangers from paan, and leaflets and posters in various languages showed the breadth of outreach work being done. Understanding the distance between our own attitudes and those of some patients we may be called on to treat is the first step in making dentistry truly available to all. Language and translation 
issues can be complicated by the decay of 'mother tongue' language skills in the second and third generations. The statistics on dental and general health and disease patterns were fascinating. Why do Vietnamese children have the worst teeth in the UK? No one yet knows.

\section{Resus-Direct}

The prize for the most useful offering should go to SAAD for their easy access, no appointment, drop-in, 'Resus-Direct', freeat-the-point-of-use facility. In tune with the government's drive-thru attitude to dentistry, hundreds of grateful dentists did a circuit of their efficient resuscitation update opportunity.

All one had to do was walk in, sign a form, watch an instruction video, move on to a manikin on the floor for practical instruction and update. The session finished with a 'patient' in the chair and the management of oxygen. There was a merchandise tie-in to supply equipment, plus certificates for framing and CPD to complete the consumer-centred experience. Free, no waiting, no ongoing commitment. Don't tell my patients! Lunches and refreshments were held in the main exhibition hall, the poster displays were there and the route to many of the scientific sessions was through that area, thus giving exhibitors good access to 'passing trade'.

\section{Litigation}

Chaired by Peter Swiss, the newly installed BDA President, a session on risk management posed the dilemma of defensive den-

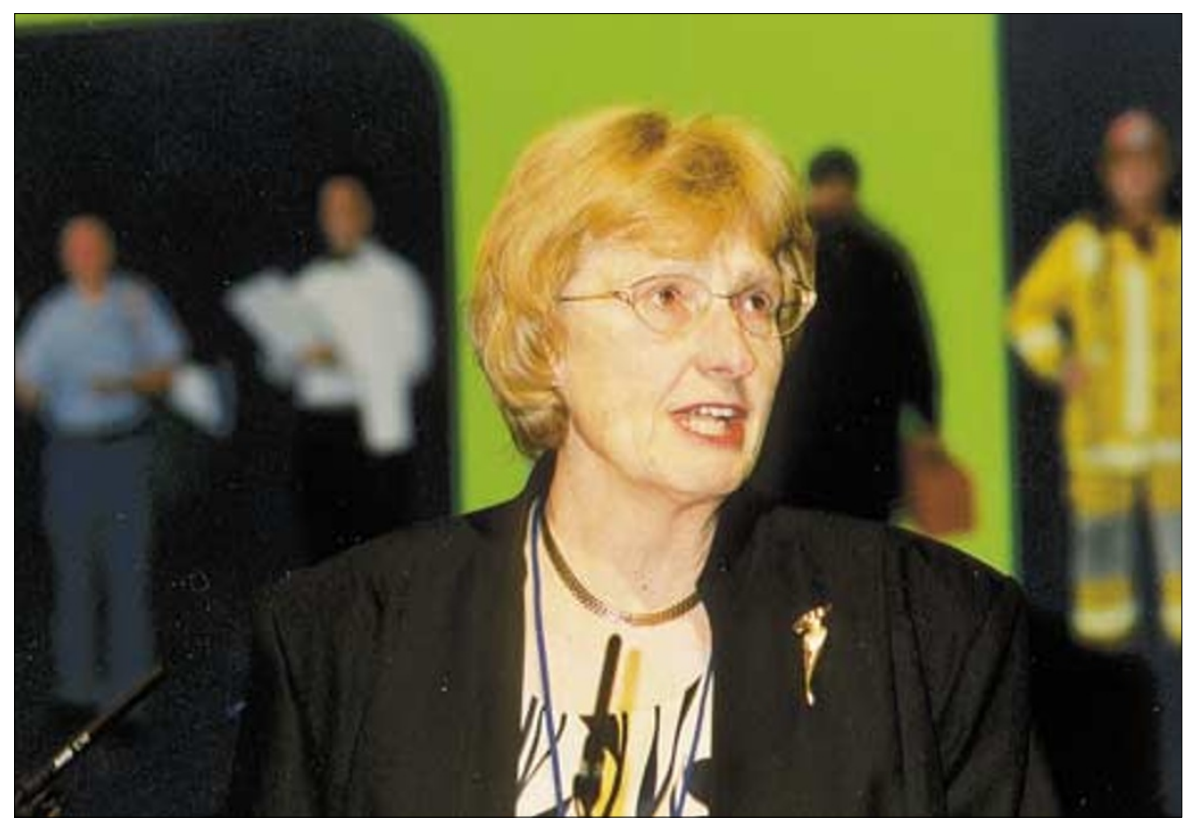

Dame Margaret Seward speaking at the conference. tistry. It carries the least risk to the practitioner, but is it in the best interest of the patient? Will it lead to under or over prescription?

In all the conference proceedings I felt the threat of litigation was colouring the line being taken. There are lawyers canvassing for cases, patients want money, awards are higher, more cases are succeeding. In the future patients may find dentists keener to stay in the mainstream and less willing to push at the barriers of what is possible. Among the catalogue of mishaps, misunderstandings and mistakes described, some drew a gasp from the innocent audience.

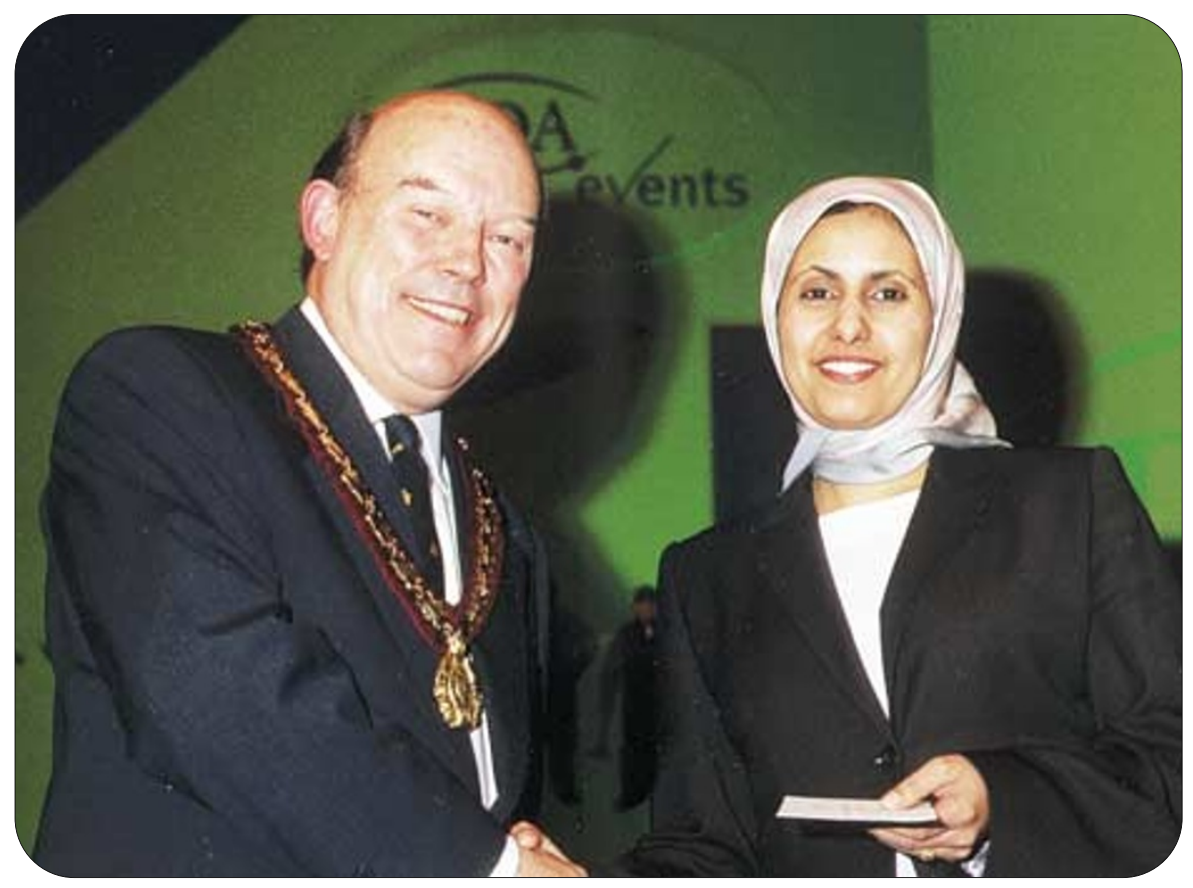

BDA President Peter Swiss hands out an award to one of the winners.
The case of the patient wearing a temporary crown who seeks treatment for pain elsewhere was one illustration. The second practitioner starts a root canal treatment. The patient returns to their own dentist and the permanent crown is fitted over the unfilled roots. The usual remedies of communication and records were advised and the need for treatment planning and monitoring was reiterated.

\section{Gillick consent}

The consensus on consent now seems to be that only the patient can consent. No one else can consent on their behalf. A parent cannot 'consent' to treatment that a 15 year old refuses. A person who is incompetent to give their own consent may be treated in their own best interests with the agreement of carers, and possibly a second professional opinion. The autonomy of the individual is paramount.

A question from the floor about consent for screening in schools led to a discussion of 'positive' and 'negative' consent. Despite the fact that those children most in need are the least likely to have parents who return consent forms, the advice was that positive consent is needed. Perhaps the older children in these groups can be informed and give their own 'Gillick' consent. The Children's Act has taken away parental rights and left only responsibilities.

Drs Howard and Lynn Myers reported the results of a nationwide survey on stress and the GDP. Over 2,000 GDPs were questioned and they secured a $50 \%$ response rate. The findings included the news that women practitioners experience higher levels of 


\section{NEWS \& NOTES $\underline{\text { best practice }}$}

stress than men. Factors such as age, geographical location and size of practice were not significant. The most important coping mechanism was to have a good network of friends. Further research is proceeding.

\section{Rambling on}

Choice, variety, information, social events were all on the programme. Attendance at the conference was high and some sessions, although not the one on dental bodies corporate, were oversubscribed. Venues were changed to larger rooms, but confusion and delay still resulted in many missing the session of their choice. A conference centre with more large rooms, or a pre-booking system might help avoid such problems.

Despite the foot and mouth disease an early evening ramble, but on quiet roads not footpaths, took over thirty hikers out into the hills and Dales. Well guided by two members of the 400 strong Harrogate Rambling Club (many national dental societies would be pleased to enrol that number) the walk ended at a village pub and restaurant. After a free glass of the local ale there was an excellent meal. As always, one of the attractions of these events is the randomness of the group and the chance to talk to new acquaintances, old adversaries or foreign visitors.

All weekend the sun shone, the shops and

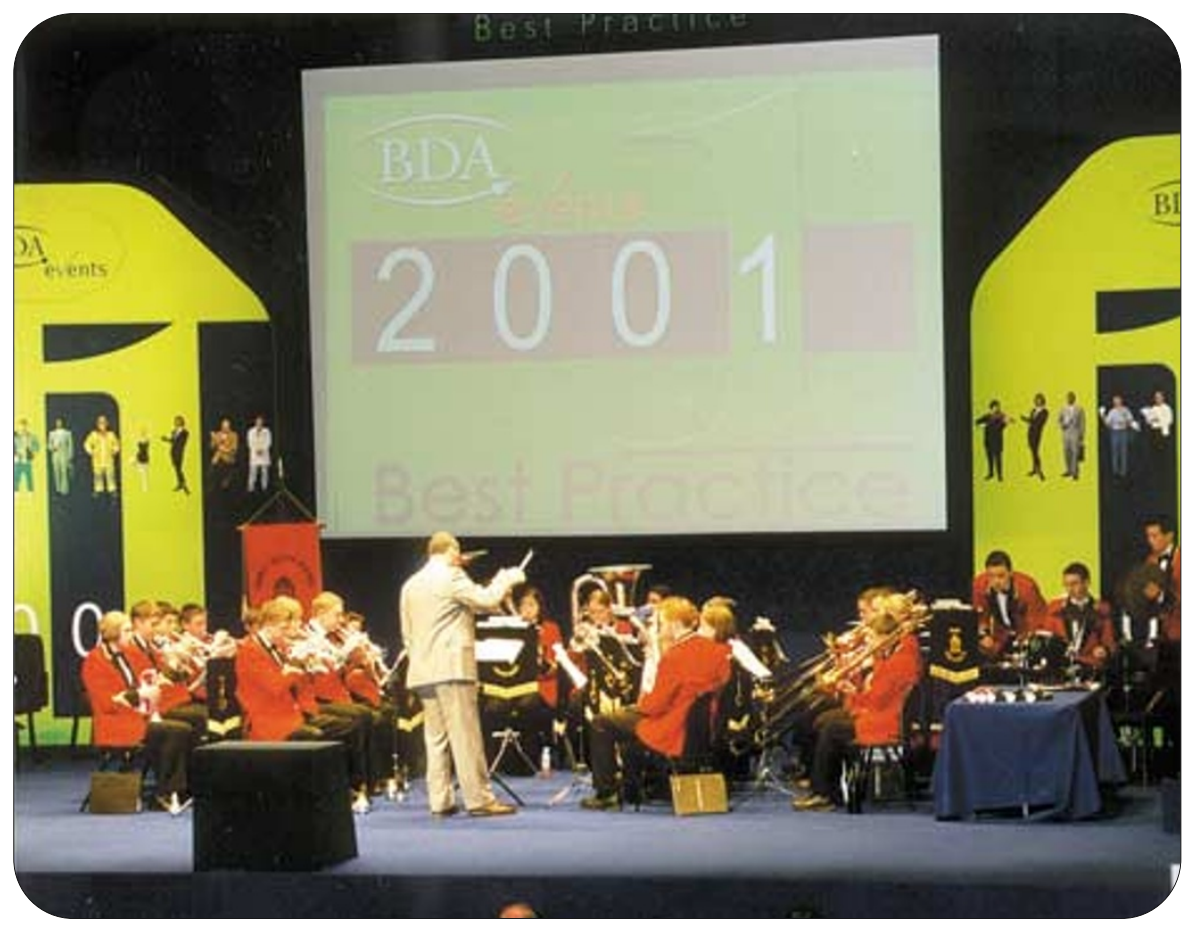

A brass orchestra helps the BDA conference get off with a swing.

teas were tempting and the town was inviting. The countryside around looked marvellous and there were still two more days left of the Bank Holiday weekend after the conference.

With a fascinating and challenging job, zero unemployment, above-average incomes and wonderful colleagues, most dentists know they are fortunate. Next year is Belfast, so charge it to the taxman, clock up the CPD credits and visit some of the nicest people in Britain and some of the prettiest country. I just hope there's another ramble.

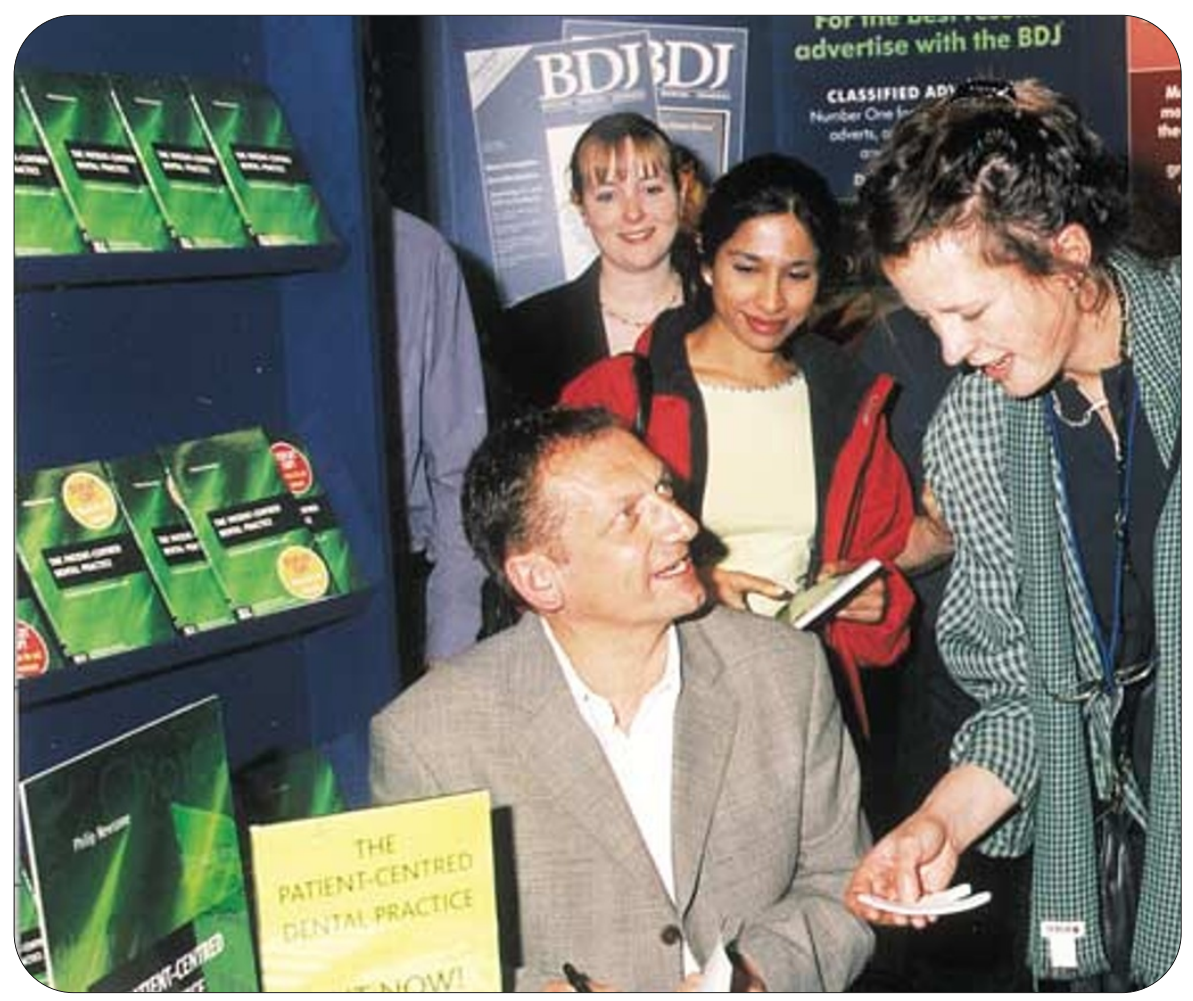

BDJ publications were on sale and author Phil Newsome signed copies of his new book.

\section{Conference sponsors}

- Bank of Ireland

- BDA Southern Counties Branch

- BDA UDT \& RW Group

- BDA Yorkshire Branch

- Denplan Ltd

- Dental Protection Ltd

- Dentists' Provident Society

- Department of Health

- Glaxo SmithKline

- KaVo Dental Ltd

- Listerine (Warner Lambert)

- Lloyd \& Whyte (Financial Services) Ltd

- Medical and Dental Defence

- Union of Scotland

- NatWest Bank

- Optident Ltd

- Stafford-Miller

- The DDU

- The St. Paul 